\title{
Ethnocentrism as a Form of Intuition in Psychology
}

\author{
Thomas Teo
}

YORK UNIVERSITY

\author{
Angela R. Febbraro \\ DEFENCE R\&D CANADA-TORONTO
}

\begin{abstract}
Ethnocentrism is conceptualized as a basic Kantian form of intuition that plays a knowledge-producing role. Although all cultures have developed their particular forms of intuition, the focus of this analysis is on Western ethnocentrism, which is discussed in four psychological manifestations. The most explicit expression of Western ethnocentrism in academia is scientific racism, which has been an important research program in the history of the science of mental life. Another manifestation of ethnocentrism as a form of intuition in Western psychology is researchers' prejudices, which play a significant role in the context of discovery. Besides these two explicit manifestations of ethnocentrism, a hidden one is analyzed, which expresses itself in terms of exclusion or disregard of nonWestern views, or in their assimilation without a reconceptualization of mental life. In this type of ethnocentrism it is assumed that Western psychological conceptualizations are superior. Finally, a fourth manifestation is discussed, which expresses itself in the institutional practices of academia, such as hiring, publishing and teaching.
\end{abstract}

KEY Words: culture, epistemology, ethnocentrism, prejudice, scientific racism

Epistemologists have long proposed that knowledge is fundamentally limited and does not mirror the natural world. The early empiricist Francis Bacon (1965) suggested at the beginning of the 17th century that purported psychological causes of human error- 'idols', as he called them-hinder human knowledge. Kant (1781/1968) suggested in his Critique of Pure Reason that knowledge is modeled according to the human mind and that things-in-themselves are essentially unknowable. According to Kant, human beings can only know and understand appearances because they approach nature with principles that precede and contribute to empirical processes. He

Theory \& Psychology Copyright (c) 2003 Sage Publications. Vol. 13(5): 673-694 [0959-3543(200310)13:5;673-694;036180] 
divided these principles into forms of intuition ${ }^{1}$ and categories. Kant identified space and time as forms of intuition, that is, physical structures that enable experience and without which objects and events would not be perceptible. He suggested that the twelve categories that he derived (causality, totality, necessity, etc.) cognitively organize objects and events of experience. $^{2}$

Let us point to an important difference between empiricism and transcendentalism. ${ }^{3}$ Most empiricists are epistemological optimists because they believe that idols can be overcome with better research practices. Kantians are epistemological pessimists because they believe that one cannot truly know the world. Yet this epistemological pessimism was not necessarily translated into research pessimism and it did not deter 19th-century Kantianinspired natural scientists, such as Helmholtz (1903), from conducting and excelling in their research activities. Neo-Kantian philosopher-psychologists such as Lange (1866/1950) abandoned Kant's forms of intuition and categories and instead argued that the psycho-physiological constitution, specifically the senses, determine what human beings can know. Lange argued that the physical features of an object that persons perceive belong not to the things-in-themselves but to the human physiological organization. Such a position did not prevent him from envisioning psychology as a rigorous natural science, for which he recommended experiments and statistics (see Teo, 2002).

The idea that socio-historical characteristics play a significant role in knowledge production has been an ongoing topic in social epistemologies. For example, Marx and Engels (1845-6/1958) argued in the middle of the 19th century that class ideology determines knowledge in the human sciences. Accordingly, the dominant knowledge of a time was the knowledge of the dominating class. The basic concepts (categories), or, more precisely, the conceptualization of terms by bourgeois human scientists (e.g. the conceptualization of freedom), are not at all universal. For Marxists, class became the central feature that determined knowledge (see Teo, 2001). Yet Marxists can be reconstructed as epistemological optimists because they believed that true knowledge-knowledge stemming from the working class-was possible. ${ }^{4}$

In the second half of the 20th century social epistemology achieved its breakthrough with Kuhn (1962), who demonstrated the defining role of the scientific community in the production of knowledge. Kuhn suggested that a research community's 'paradigm' enables research, defining what research questions and methods are allowed, and determining what is perceived. Kuhn could be read as an epistemological pessimist who underlines the fundamentally limited nature and incommensurability of all paradigmatic knowledge. However, there have been attempts to interpret him as an epistemological optimist as the paradigmatic limitations of research can be overcome through better research (see Stegmüller, 1979). What Kuhn 
demonstrated for the natural sciences, Foucault (1966/1970) accomplished for the human sciences, as he understood human-scientific knowledge of a certain age and era in terms of an historical episteme. ${ }^{5}$

Another significant social epistemology was developed by feminists, who introduced the idea of gender as a form of bias in knowledge production (Febbraro, 1997). Feminist philosophers such as Harding (1986) have illuminated the ways in which knowledge is socio-historically mediated, and have argued that modern science has been conceptualized in androcentric terms; that gender symbolism, the assignment of gendered dualistic metaphors, the gendered social structure of science and the masculine gender identity of individual scientists have influenced the concepts, theories, methods, interpretations and goals of science (see also Alcoff \& Potter, 1993; Harding, 1991; Keller, 1985). Because of the functional equivalence between concepts such as gender and ethnicity, feminist philosophers of science have also begun to draw close attention to postcolonial studies and have included them in their reflections on science and knowledge (e.g. Harding, 1998). Postcolonial thinkers emphasize the role of imperialism in Western thought (e.g. Said, 1993; Spivak, 1999) or the role of subcultures in the sciences' ways of knowing (Collins, 1991).

We suggest that it is possible to reconstruct social epistemologies as reconceptualizations of Kant's forms of intuition. Instead of a priori physical principles such as space and time (Kant), and instead of human physiological determinants of knowledge (neo-Kantianism), social philosophers have focused on social structures (class, gender, paradigm, episteme, colonialism, subcultures) as forms of intuition (e.g. gender produces gendered knowledge). Yet, more importantly, we propose here that space and time can be understood socio-historically as factors that condition what humans are qualified to know. Physical time is then conceptualized as historical time, and physical space is understood as cultural space. Accordingly, the time in which one lives, and the context that socializes human beings-for example, West or East, North or South, first or third world, developing or developed country, colonized or colonizing country, and so on-become sociohistorical forms of intuition that inform and structure one's everyday experiences as well as one's academic knowledge. And even more Kantian: without these forms of intuition, knowledge would not be possible.

An important characteristic of these socio-historical forms of intuition is their 'centrism'. 'Time-centrism' (not a focus in this article) means that a given time ('our time') is the criterion from which knowledge is produced and understood. Current knowledge is not judged in terms of the future, which is obviously impossible (i.e. one does not use the year 2200 as the criterion for contemporary knowledge), and knowledge is usually not evaluated in terms of the past, which is possible, but-with the exception of historians - present knowledge is usually not compared, for example, with the knowledge of the Middle Ages (because it is often assumed that 
contemporary knowledge is superior). On the other hand 'ethno-centrism' means that one's own ethnicity (better: culture or group) is the criterion from which knowledge is produced and understood. The term 'ethnocentrism' ${ }^{6}$ used in this epistemological sense is a form of intuition and thus a precondition for the production of 'knowledge'.

As science is part of culture, forms of intuition are not limited to everyday life but play a significant role in academia. Psychologists usually-quasinaturally-perceive psychological phenomena based on how they have experienced them and how they have learned to perceive them in their particular cultural context, which includes their academic institutions. In this sense, epistemological ethnocentrism is an a priori principle before any empirical research is conducted (and 'empirical research' itself assumes a particular cultural perspective). Ethnocentrism can also be made into a program when it is suggested, for example, that Western forms of intuition and Western categories are superior to non-Western ones. Given that our own background is Euro-North-American and that we are most familiar with 'Western' psychological theories and research practices, we will focus on Western ethnocentrism (i.e. eurocentrism ${ }^{7}$ ) in psychology.

Ethnocentrism is a universal form of intuition in the sense that all cultures have their specific frameworks for producing knowledge and making experiences. Moreover, various cultures have also developed their own particular categories with which psychological issues are addressed (see Danziger, 1997). ${ }^{8}$ In middle-class Western everyday contexts, for example, one might use the concept of a defense mechanism or reinforcement in order to explain a certain human behavior, and, in academic life, one might refer to variables in order to structure psychological information. Usually one is not aware of the fact that psychological categories are located within a particular sociohistorical tradition, and, more importantly, this fact is not used to relativize one's experiences and what one considers as true. Ethnocentrism as a form of intuition is not an ideology because the term would suggest in its Marxist reading that Euro-American psychology is necessarily false whereas nonEuro-American psychologies are true. Such a position is, according to our understanding, epistemologically indefensible and contradicts the argument proposed here.

\section{Manifestations of Ethnocentrism}

Understanding ethnocentrism as a form of intuition is epistemologically pessimistic in the sense that all psychological knowledge is culturally situated, that is, Western academic theories and scientific research practices as well as Eastern thought systems are located within epistemologically particular cultural traditions. More significantly, such a position may be seen as epistemologically optimistic because 'other' socio-cultural forms of 
intuition as well as categories are improvable and malleable, that is, teachable and learnable. Although it is impossible to transcend time in a forward direction (it is not meaningful to predict how psychological theories will be conceptualized in 200 years, for example), it is possible to transcend and fuse socio-cultural contexts in order to extend human knowledge. For example, Western individuals increasingly possess multicultural and multiethnic backgrounds or experiences, which prepare them for such a fusion, and broaden their form of intuition. Academic psychologists, if they have the desire and the opportunity, can learn more about various cultures' ways of conceptualizing psychological issues. With effort, will and institutional support it is possible to transcend eurocentric viewpoints and to develop multiculturally informed basic concepts for psychology, even when a complete global perspective may never be reached.

Eurocentrism as a form of intuition does not express itself in a single way. In order to provide a more systematic mapping of the problem of epistemological ethnocentrism, we suggest looking at four different manifestations. The first manifestation of eurocentrism is the most obvious one, namely a perspective in which eurocentrism is the explicit stand. It can be found most prominently in the research program of scientific racism, in which certain human groups are constructed as inferior and Europeans are conceptualized as the champions of evolution. The history of psychology shows an abundance of evidence for scientific racism as a research program (see Guthrie, 1998; Richards, 1997).

Eurocentrism not only expresses itself in the scientific community as a research program; psychologists may also look at the role of individuals in the context of discovery. Thus, it is important to examine the second manifestation of eurocentrism, namely individual prejudices of academics in the process of research production. These individual prejudices play a role in the selection of research questions, the phrasing of hypotheses and the interpretation of data. This does not mean that one should neglect the connection of individual prejudices with the socio-historical context, but it does mean that one should also look at inter-individual differences among researchers.

These two forms of ethnocentrism (ethnocentrism expressed in the research program of scientific racism and individual ethnocentric prejudices) are probably the most accepted ways of thinking about ethnocentrism from an epistemological point of view. The real contemporary challenge comes from a hidden ethnocentrism, which is not necessarily expressed in prejudices, but, for example, is shown in a conceptualization of mental life assumed to be of universal validity. In this third manifestation of ethnocentrism, which is difficult to detect, non-Euro-American views are not taken into account and only Euro-American perspectives of an object, event or story are discussed. This manifestation is grounded on the more or less 
tacit assumption that ideas that have been developed in peripheral intellectual and cultural contexts are irrelevant for the theory and practices of science (see Harding, 1998) - including the science of mental life. We suggest that such a hidden ethnocentrism cannot be overcome by colonizing non Euro-American views into Western psychology as long as it is based on the idea that Western psychology is superior to non-Western ideas of mental life. This hidden ethnocentrism is often performed without any 'bad intentions' in a process of exclusion, neglect or assimilation.

The fourth manifestation of academic ethnocentrism expresses itself in academic institutions. Inside players familiar with the game of Western academia have a much higher chance of succeeding than players outside of this context, even when outsiders have significant knowledge and expertise about the mental life of their context, for they may not play the publication and research game. Although we have suggested that each culture has developed its own categories and that ethnocentrism is a basic form of intuition in all cultures, this does not mean that there is fair and equal competition among various psychological conceptualizations. EuroAmerican psychology comes with a whole apparatus of power (money, infrastructure, technologies, cultural support) that does not provide other ideas the same footing for their distribution.

\section{Scientific Racism}

The most explicit academic manifestation of ethnocentrism can be observed in scientific racism, which has been an important research program in academia and has influenced the Zeitgeist of Western society (see Barkan, 1992; Hannaford, 1996; Malik, 1996; Miles, 1989; Stepan, 1982). Scientific racism has been a 'paradigm', and adherents of scientific racism have consented to the notion that European 'races' are superior to non-European ones. ${ }^{9}$ Concepts such as 'race' and the idea that differences are natural have been accepted and unquestioned. Hypotheses, results and interpretations have been arranged within this worldview and, as a basic tenet of this program, results have been assumed before data were collected (see Gould, 1996). Academic results had and still have profound consequences for ethnic minorities in the public and political sphere.

Pioneers of psychology and American Psychological Association presidents were among the leaders of scientific racism (see Richards, 1997; Tucker, 1994). Much of the academic research of these pioneers becomes understandable, as the work of a behaviorist or psychoanalyst is understandable, within the 'paradigm' of scientific racism. And although scientific racism has been on a steady decline, researchers such as Rushton (1999) 
show that it is an ongoing project. He calls upon objectivity and truth in order to promote his research without recognizing that his research is part of a worldview that is constructing his empirical results (see Winston, 1996).

We suggest that scientific racism follows a specific 'logic' (i.e. it follows certain cognitive rules) that we would like to describe (see also Memmi, 1982/2000) notwithstanding the existence of a variety of racisms (see Ernst \& Harris, 1999). First of all, the reality of biological races is taken for granted, despite that fact that many experts conclude that 'race', when applied to humans, is not a natural-scientific concept (Montagu, 1974; Tate $\&$ Audette, 2001). The morphological discourse on the construction of 'races' is weak; scientific racists themselves have been unable, for example, to provide a consensus on the number of 'races', and leading geneticists such as Cavalli-Sforza and Cavalli-Sforza (1995) argue, based on biological considerations, that 'the idea of race in the human species serves no purpose' (p. 237).

Levin (1997) points out that racial classifications are inadequate for logical reasons (arbitrariness of classifications; failure to distinguish groups; lack of correspondence to linguistic or cultural groups), as well as for statistical reasons (greater variance within than between populations; the inability to discover a single characteristic that can be associated exclusively with one racial population). Instead of discrete separate groups, scientists find a continuity of variation. Levin's conclusion is that 'race as a category of evolution or a major division in the human species is unsupported. The repeated attempts to demonstrate the separation of races by reduction of morphological characteristics to genetic differences have largely failed' (p. 38). Corcos (1997) reminds one that human beings inherit not 'race' but 'genes that dictate skin color, hair, the shape of nose or lips, and so on' (p. 34).

In this context, conceptual lessons can be learned from feminism. Feminist theorists with respect to the concept of sex/gender emphasize the overlap that exists between women and men in terms of gendered (so-called 'feminine' or 'masculine') behavior; they point out that variation within one gender is much greater than variation between genders, and that gender differences, when found, are usually small and often related to social context (Crawford \& Unger, 2000). These empirical arguments suggest that the social concept of gender is an artificial dichotomy, and that even the biological concept of sex is suspect, as the most basic, biological aspects of sex are neither fixed nor universal, and biological sex is not always unitary, but may exist on a continuum (Stoltenberg, 1989). Feminist critics further point out that in sexist discourse, differences between women and men are naturalized or essentialized and women are evaluated as deficient according to a male standard (Tavris, 1992). According to such critics, sexual or gender dichotomies are a result of both androcentric and ethnocentric/ 
cultural biases, and sexual or gender dichotomies have been used to maintain the existing social and political order. In short, feminists view the concept of sex/gender as a social-political construction that has been used to serve the interests of the patriarchal status quo (Penelope, 1990).

Such arguments do not discourage proponents of contemporary scientific racism (or sexism for that matter) from upholding the so-called 'reality' of different races, which is their first credo. But because ethnocentrism is the basis for scientific racism's logic, not only do researchers believe in the reality of various races but they must also construct differences between the construed races (see Teo, 1999a). Proponents of scientific racism in psychology use the methods of the empirical sciences in order to construct these differences. These differences are evaluated in favor of Europeans. This evaluation may range from emphasizing characteristics that are relevant to the European worldview, to choosing labels so that Europeans can be understood as the psychological norm, to explicit value judgments. Hand in hand with the evaluation of these race differences comes the naturalization of differences, which means that these differences are attributed to the biological nature of the different races. Scientific racism would have been an insufficient worldview if researchers believed that these differences were a matter of socio-historical development. As differences were not understood as cultural, historical or political-economic, evolutionary theory proved to be a most useful tool for the naturalization of differences (Spencer, 1972).

An examination of the context of discovery for the concept of 'race' shows that race systems have seldom focused solely on the phenotypic diversity of humans. The discourse was concerned with meaning constructions for political, economic and military purposes (see Mecheril \& Teo, 1997). Knowledge was produced within the context of European colonization or American slavery in order to justify, within a systematic ideology, inhuman practices. Thus, these ideological aspects (construction, evaluation and naturalization) were used by experts of scientific racism or by politicians in order to recommend and execute practices against groups constructed as inferior, while empirical research was used to legitimize these practices (e.g. Davenport \& Steggerda, 1929). If one looks at the function of knowledge production (see Teo, 1999b) in scientific racism, one realizes that research was performed under the function of providing and producing ethnocentric meaning for Western cultures (see Adas, 1993; Prakash, 1999). However, this original goal of providing an ideology of meaning was hidden behind a scientific veneer. Scientific racism in psychology is extremely powerful as an ideology because it uses the cherished standards of scientific psychology: operational definitions, variables and, most of all, statistical methods. Because of the portrayal of science as objective, neutral and empirical, in the public sphere it is sometimes difficult to convey the ethical as well as the epistemological-ethnocentric limitations of scientific racism. 


\section{Researchers' Prejudices}

The sociology of knowledge emphasizes that knowledge production is located within paradigms. A psychology of knowledge (e.g. MüllerFreienfels, 1936) is concerned with individuals who choose certain paradigms and examines their motivations, unconscious motives, group dynamics, and so on. Specifically, a psychology of science would attempt to uncover why a particular individual joined the research program of scientific racism. Reichenbach (1938) confined the philosophy of science to the context of justification and attributed the context of discovery to the psychological domain. However, epistemologists interested in a comprehensive picture of knowledge cannot exclude the context of discovery, and psychologists are of course obliged to answer the basic question: why is someone interested in research on 'races' or in racist constructions? As it is difficult to provide general answers, it is important to carry out concrete studies, which tend to be more social-historical than psychological (e.g. Weidman, 1999).

Bacon (1965) discussed 'idols of the cave' in order to address the intellectual peculiarities of individuals, and suggested that individual 'prejudices' of researchers are a problem in the pursuit of empirical knowledge. ${ }^{10}$ Nowadays we would add that these are mediated by cultural-historical or systemic prejudices. Although there have been plenty of studies on racial prejudice in the general population, and in fact there is a whole industry of prejudice research in social psychology (see, e.g., Dovidio \& Gaertner, 1986; Jones, 1997), empirical studies on racial prejudices among academics have been neglected. Science is seen as a rational enterprise, and the scientific community does not look favorably upon pointing to prejudices or irrational and unconscious motives in the context of discovery.

Some psychoanalytically inspired studies have been relevant in this research area. One could paraphrase Adorno, Frenkel-Brunswik, Levinson and Sanford (1950) and ask: what is there in the psychology of an academic that renders him or her prejudiced? Although Adorno did not concern himself with scientists in his studies on the authoritarian personality, it seems important to do so in order to understand the context of discovery more adequately. Yet it may be difficult to convince racist psychologists to participate in studies that try to elucidate idols of the cave in race research. Moreover, such an approach would be epistemologically limited if it did not take the socio-historical dimension into account, elucidating how individual prejudices are mediated by cultural ethnocentrism as a form of intuition.

Perhaps a psychology of science would allow us to understand why comparing the penis size of various 'races' is of interest to male researchers and psychologists. Dr Serres sought to prove scientifically in the 19th century why a white man could have sex with a black woman but why a 
white woman should not have intimate relations with a black man. Impressed by the lengthy penis of the Ethiopian (African) race, he argued that 'this dimension coincides with the length of the uterine canal in the Ethiopian female' (Serres, as cited in Broca, 1864, p. 28). From this physical reality follows 'that the union of the Caucasian man with an Ethiopian woman is easy and without any inconveniences for the latter' (p. 28). The case is different in the union of the Ethiopian man with a Caucasian woman, "who suffers in the act, the neck of the uterus is pressed against the sacrum, so that the act of reproduction is not merely painful, but frequently nonproductive' (p. 28).

Richards (1997) points out that Galton's racism was not only constructed in his writings but also practiced during his travels, when he included punishments such as pouring boiling water on the naked bodies of his servants in his court of justice. He emphasizes that Galton's racist attitudes were formed in his twenties during his expeditions to Africa and that in his mature work he did not change his racist beliefs. That is, Galton's racism was formed before he had collected any scientific data. Similarily, Fancher (2001) shows that eugenics played for Galton the role of a secular religion, replacing his conventional faith, which had been crushed by his conversion to evolutionism.

We think it is a fair assessment to suggest that most contemporary psychologists view scientific racism and blatant racial prejudices and actions as an aberration of the discipline's past. Indeed, Samelson (1978) showed the discipline's shift from race research to prejudice research in the first half of the 20th century. Although there are still proponents of scientific racism, who are not marginalized in terms of access to psychological journals and public attention (e.g. Rushton), we agree that contemporary psychology's mainstream would reject prejudicial premises. This does not mean that there is not plentiful evidence of the social pervasiveness of everyday racism (Essed, 1991). From a perspective of ethnocentrism as a form of intuition we suggest that researchers must look at the premises that enable psychological research, including research on prejudice.

The film Rashomon, directed by Akiro Kurosawa, comes to mind when describing Western psychologists. Several witnesses in medieval Japan see a rape and murder but provide entirely different accounts of what happened. Instead of focusing on the personal or social construction of reality, one could use Rashomon as an example of the distortion of truth. Each witness presents a deformed view of what had actually occurred. The philosophical problem does not lie in this particularism, because, we argue, any form of intuition starts in a particular context. The problem lies in the assumption that one's own story is not particular, and in a refusal to listen and learn from others' perspectives. The argument applies to all cultures, but because we are interested in eurocentrism we focus on Western knowledge. This does not mean that one should not study, for example, various Eastern 
ethnocentrisms (see also Shelton, 2000). However, any comparison between Western and Eastern ethnocentrism cannot neglect a study of the consequences and the impact of economic and military power in the social practice of ethnocentrism.

\section{Hidden Ethnocentrism}

Already everyday experiences of multiculturalism teach us that there are different cultural narratives on important psychological issues. One can make the argument that academia must be more sophisticated than to base its concepts on particular experiences and must routinely study other cultures' conceptualizations historically (prototypically performed by Danziger, 1997) and systematically. Yet, if psychologists know that there are various conceptualizations of a mental object or event, and they report only a particular conceptualization, or suggest that only one particular conceptualization makes sense, or imply that the Euro-American one is superior, then they have accepted their culture's form of intuition as the standard. If researchers are not aware of 'peripheral' conceptualizations and instead universalize Euro-American conceptualizations, then they have acknowledged a particular form of intuition as the universal one.

It seems epistemologically self-evident that psychologists should disclose as many conceptualizations as possible in order to develop a comprehensive understanding of mental life. These conceptualizations may or may not differ from Euro-American ones; however, researchers cannot answer this issue a priori. Academics in the human sciences and in psychology who are not willing to inquire about alternative constructions in other cultures or subcultures must either admit from the beginning that their knowledge is particular, Western-focused and eurocentric, or they must accept the assessment that they are part of the hidden ethnocentrism of Euro-American psychology. $^{11}$

When it comes to socio-historical concepts such as subjectivity, identity, intelligence, emotion, motivation, personality, and so on, Euro-American researchers tend to teach, write and act as if they have told the whole story of human mental life. In fact, they tell only a few parts of the story, a story that is largely influenced by the history and context of Euro-American history, culture and science (see Spivak, 1999). It is epistemologically premature to suggest that Euro-American conceptualizations of personality, for example, are universal. ${ }^{12}$ These conceptualizations are then sometimes applied to other contexts and supposedly support the cross-cultural authority of these conceptualizations. However, they do not prove the cultural validity of the concepts, only their universal administrative applicability. ${ }^{13}$ As Howitt and Owusu-Bembah (1994) observe in their straightforward assessment: 'No studies attempted to explore, for instance, Ghanaian or Chinese 
personality structure in their own terms rather than through these Western terms' (p. 119).

Psychologists must be aware of practices that Said (1993) describes so eloquently:

The universalizing discourses of modern Europe and the United States assume the silence, willing or otherwise, of the non-European world. There is incorporation; there is inclusion; there is direct rule; there is coercion. But there is only infrequently an acknowledgement that the colonized people should be heard from, their ideas known. (p. 50)

In line with this argument, we suggest that a hidden ethnocentrism is not overcome by simply assimilating ideas from other cultures, which would be a colonizing approach. In other words, a solution to hidden ethnocentrism requires a process of accommodation as well as assimilation. ${ }^{14}$ EuroAmerican human scientists must be willing to completely revise conceptualizations, if necessary, and not simply add to them.

A sober analysis shows that most of mainstream psychology falls under the notion of hidden ethnocentrism, and thus we agree with Howitt and Owusu-Bempah (1994) that 'eurocentrism describes the orientation of much of the social sciences, especially psychology' (p. 114). Many psychologists may even possess a consciousness about this problem and would like to delegate their epistemological duties to cross-cultural psychology. As important as cross-cultural research has been in advancing psychology's knowledge of culturally varying behaviors (e.g. Choi, Nisbett, \& Norenzayan, 1999), the hope that normal cross-cultural psychology would overcome hidden ethnocentrism is shortsighted, as long as it does not consider new conceptualizations and methodologies for psychology (see also Bhatia \& Ram, 2001). We emphasize that it is important not only to look, for example, at different patterns of attribution but also to study the meaningfulness of the concept of attribution in other cultures. A crosscultural psychology that does not address hidden ethnocentrism may be well-intentioned but, nevertheless, consolidates Western forms of intuition and Western categories. As Harding (1998) emphasizes in her advancement of postcolonial epistemologies: 'The distinctive way that cultures gain knowledge contributes to their being the kinds of cultures they are; and the distinctiveness of cultures contributes to the distinctively "local" patterns of their systematic knowledge and systematic ignorance' (p. 6).

Paranjpe (1998) reports in his important book on Indian and Western psychology about an international psychologist who staunchly argued that science and the concept of falsification are Western inventions. Paranjpe (p. 18) shows that this is false, that Indian philosophy had developed sophisticated epistemological ideas, including those of falsification. Statements that assume a priori that there is no need to look at other cultures' ideas or conceptualizations emerge from ignorance and show how deeply 
hidden ethnocentrism is part of Western thought. Paranjpe's analysesbased on knowledge of the epistemological, ontological and ethical foundations of psychology in both the West and India-instruct one to recognize the similarities and differences of two culturally diverse systems on person, self and identity, and demonstrate that psychological concepts are often of a social, historical and cultural kind.

Kohlberg's theory, which has already been criticized from many points of view (see Teo, Becker, \& Edelstein, 1995), provides another example from developmental psychology. There is no doubt that Kohlberg $(1981,1984)$ had good intentions when he developed a stage theory of moral development. In order to prove the cross-cultural validity of his theory, he tested it in different cultures. But the testing of different cultures does not lead to a cross-cultural conceptualization of a theory of moral development. The ability to respond to a Euro-American theory does not constitute the validity of a theory. Kohlberg would have needed to understand the conceptualization of morality in diverse cultures, which might have led to a different conceptualization of moral development, and, perhaps, a culturally different voice (cf. Gilligan, 1982). In not doing so, he contributed to hidden ethnocentrism in an epistemological sense.

Holzkamp $(1973,1983)$ suggested an ingenious approach to the construction of psychological concepts. He argued that a real understanding of the psychological subject matter would only be possible if the natural history, the pre-history and the history of humanity were included in the analysis. He suggested three steps in analyzing psychological concepts. In the first step, one must incorporate the natural history of the issue and identify general evolutionary-biological characteristics. In the second step, one must analyze the main features of the topic with regard to their general societal-historical characteristics by focusing on the transition from pre-human to human lifeforms. In the third step, one must clarify perception under a given historicaleconomic reality such as bourgeois society (see Teo, 1998). Although it may be correct that most contemporary societies are based on a capitalist mode of production, such a description is indifferent to the socio-historical specificity of various socio-cultural contexts and their conceptualization of psychological topics. In order to understand the concept of the 'self', we may look at what 'self' means in capitalist society, but this is certainly not sufficient in order to understand conceptualizations of self in various cultures. In that sense any conceptualization of psychological concepts based on an analysis of Western bourgeois society is part of hidden ethnocentrism. ${ }^{15}$

The idea that one can export Euro-American psychological concepts into other cultures is based on a natural-scientific model of science: naturalscientific laws are universal and can be found in any culture. We would agree with Dilthey (1883/1959) that there are important differences between the natural and human sciences. Dilthey, in justifying the human sciences (Geisteswissenschaften), pointed out that their subject matter is historical- 
social reality and therefore their method must be different from the natural sciences. This also means that their concepts cannot transcend space and time. More recently, Danziger, in Naming the Mind (1997), pointed to the historical dimension of concepts such as intelligence. He emphasizes that 'cultural embeddedness accounts for the taken for granted quality that so many psychological categories possess' (p. 191). These psychological concepts appear natural to a given speech community, although historical and cultural research indicates that most psychological categories are not of a natural kind.

Euro-American psychology often assumes that psychological concepts that have been developed in Euro-America are unquestionably culturally valid. We suggest that, as a consequence, psychologists perform poorly in understanding mental life in other cultures. Understanding mental life requires an understanding of the objective mind (Hegel) of the culture or subculture under investigation. Understanding the mental life of an individual from another culture or subculture also requires taking into account his or her context, history, categories and forms of intuition. If Western psychology intends to be objective, it cannot remain within the boundaries of its own conceptualizations. Unfortunately, in the process of academic and intellectual globalization, we expect less interest by Western psychologists in non-Western psychologies, but rather an increased interest of nonWestern psychologists in Western psychologies, which are associated with power, money and influence.

Explicit ethnocentrism has been the objective mind of Western society for several hundred years. Some of the greatest Western thinkers, including Immanuel Kant (1724-1804) and Georg Wilhelm Friedrich Hegel (1770-1831), were trapped in this mindset. However, in contemporary thought, hidden ethnocentrism has become the objective mind of Western thought, and most of mainstream psychology's concepts have been based on a hidden ethnocentrism of knowledge production: It has been assumed implicitly that Western conceptualizations of human subjectivity are superior to others. It is considered so self-evident that it requires no further explanation or elaboration; it is the collective unconscious of Western psychology.

\section{Ethnocentrism in Academic Structures}

Psychological science can be described as a game with many institutional rules. Important moves in the game include publishing papers, presenting ideas, applying for research grants, participating in various peer-review processes, communicating with colleagues and, last but not least, teaching. The significance of streamlined institutional behavior for the production of normal science has been understood by sociologists of science (Kuhn, 1962). 
Institutions, embedded within a given society, are the concrete locations in which research is executed. These institutions may range from explicit racist institutions, such as fascist institutes of 'racial hygiene' (Weingart, Kroll, \& Bayertz, 1988), to contemporary benevolent academic departments. Hidden ethnocentrism, as reflected in academia as an institution of knowledge production, refers to the neglect and exclusion of experts who have knowledge and experience from other cultures and subcultures, of experts who may have different conceptualizations of psychological topics or even different ways of knowing (Collins, 1991).

In order to change the eurocentric character of mainstream psychology, it will not be sufficient to simply listen to new ideas and conceptualizations. It would be naïve to assume that alternative forms of intuition would prevail without institutional support. Therefore, concrete practices and policies are needed in order to change the structure of academia. One could label such a process as 'affirmative action' for alternative forms of intuition. It must be emphasized that affirmative action for alternative cultural knowledge and experiences is more important than affirmative action for traditional ethnic divisions-even when at the moment these experiences often go hand in hand. It is clear that affirmative action for experts from postcolonial countries would require not only academic, but also major political and legal, changes.

Other examples of hidden institutional ethnocentrism can be found in the channels of academic communication, such as journals. Howitt and OwusuBempah (1994) report that they 'have been told by white journal editors that the language we use in academic papers is unacceptable and has to be toneddown or removed as a condition of acceptance for publication' (p. 136). Asking for a change in tone, streamlining arguments and other revisions can be used as an instrument to censor papers that use a different voice. This is not censorship in a crude way but it expresses the 'repressive tolerance' of Western academia, according to which papers are accepted as long as they are palatable to the mainstream.

Hidden institutional ethnocentrism is also expressed in teaching. For example, a Euro-American history of psychology may be fascinating to Euro-American students. It may even be interesting to non-European students because Western pioneers of psychology (e.g. Freud) address important issues and are part of mainstream culture. However, psychologists often teach Euro-American psychology as if no other psychologies existed. By not teaching non-Euro-American ideas on human subjectivity, teachers perpetuate and consolidate one form of intuition. The changing ethnic structure of student populations in many urban centers in North America may one day change the content of courses by demand. But until then, psychologists who are truthful and committed to knowledge must admit that psychology courses are taught from a Euro-American perspective. Most 
psychologists must admit, for example, that instead of a history of psychology, they teach a history of Euro-American psychology. Instead of a theory of personality, they focus on a Western theory of personality. Instead of an introduction to psychology, they teach a Western introduction to psychology. Instead of writing a textbook of social psychology, they write a textbook of Western social psychology. Such a change in perspective would involve admitting that psychologists' knowledge is profoundly limited.

\section{Conclusion}

Psychologists are frequently not aware of the problem of ethnocentrism, especially in its hidden form. There are often no bad intentions involved, and in a Kantian ethical tradition one has learned that good intentions must be valued above all. Yet we have discussed ethnocentrism as a form of intuition from an epistemological and not a moral perspective. We are not interested in using ethnocentrism as a moral yardstick in order to condemn Western researchers or to provoke personal guilt. Our discussion is not about blaming Euro-American scientists and calling them eurocentrists. Our interest focuses on the limits and possibilities of Western psychological knowledge, on what psychologists are doing, and on challenging and being open to extending the knowledge on human mental life. The argument is not about moral but about epistemological responsibility. ${ }^{16}$ Such responsibility has recently been shown in philosophy by Harré (2000), who specifically includes non-European perspectives in his history of philosophy. He discusses Indian, Chinese, Japanese and Islamic thought systems in their own rights without assimilating them into Western concepts-an important step for a postcolonial philosophy.

Our epistemological argument is also based on Hegel's (1807/1986) idea that 'truth is the whole' (p. 24). Hegel believed that he was able to know and embrace totality. Based on his hidden and explicit ethnocentrism and his belief that the West is the center of truth (see Dussel, 1992/1995), he did not understand fundamentally the real content of his statement. From a truly global perspective, we suggest that his statement should receive a new meaning: a multicultural, postcolonial and post-eurocentric meaning that Hegel could not have envisioned in the early 19th century. Thus, in order to be consistent with our own argument-we only marginally include other cultures' notions of knowledge-we must re-title this article as: 'Ethnocentrism as a Form of Intuition in Psychology: A Western Perspective'.

\section{Notes}

1. The German term Anschauungsformen has been translated as 'forms of intuition', 'forms of sensibility' and 'forms of perception'. The English term 'intuition' may be problematic because in contemporary English it connotes 
some kind of immediate apprehension, which conflicts with Kant's meaning. However, it has become the customary English translation.

2. For example, the human mind imposes cause-and-effect relationships on the material of perception (i.e. the natural world).

3. Kant's program is labeled 'transcendental philosophy' because he was interested in the a priori of human knowledge.

4. Later, feminist standpoint theorists suggested that true knowledge comes from the margins (i.e. women and minorities).

5. An episteme refers to an era's cultural matrix with which the world is approached and understood.

6. For a general definition, see Gergen and Gergen (1984). Instead of the word 'ethnocentrism', we would prefer 'culture-centrism' for our argument. However, this term has no social-scientific tradition.

7. The term 'eurocentrism' includes in this argument the notion of 'americacentrism'. Moreover, caution is required in using the term 'eurocentrism', because a few countries (e.g. Germany, France, Great Britain) dominate the academic constructions of Europe. The terms 'East', 'West', 'Euro-America', and so on, are all problematic in their delineation, but for the lack of better alternatives we apply them here. Malik (1996) has emphasized the problematic nature of the terms 'East' and 'West' in his critique of Said (1979).

8. Holzkamp (1983) identified the importance of categories in psychological thought and pointed out that psychological categories such as behavior, stimulus, reinforcement, emotion, cognition, and so on, are used without being tested. He considered this situation the central problem of a scientific psychology (see also Tolman, 1994).

9. The followers of the Nordic doctrine believe that within Europe the Nordic 'race' is superior.

10. The epistemological conceptualization of ethnocentrism as a form of intuition through which objects and events are perceived is different from the concept of a prejudice (see Jones, 1997). In this argument, prejudice is considered one manifestation of ethnocentrism.

11. There is a conceptual similarity to Gaertner and Dovidio's (1986) notion of 'aversive racists', who believe that prejudice is wrong, that they are egalitarian, yet they are unaware of their negative racial attitudes. In hidden ethnocentrism it is also believed that racism, ethnocentrism and prejudice are wrong, but one is not aware of the ethnocentric dimension of one's form of intuition and one's categories.

12. This universalization is considered legitimate because it is based on a scientific methodology. However, a natural-scientific methodology cannot prove the universal character of a category.

13. The ability to administer, for example, intelligence tests in another culture proves the applicability of the test in this culture, but does not say anything about the validity of the test for this culture.

14. We use the terms 'assimilation' and 'accommodation' in a Piagetian sense.

15. One could argue that one should propose a purely formal theory of the self void of any cultural content. But a theory that does not take content into account is indeed empty. 
16. Truth and truthfulness may be considered moral categories too, but in this argument we emphasize the traditional epistemological dimension.

\section{References}

Adas, M. (Ed.). (1993). Islamic and European expansion: The forging of a global order. Philadelphia, PA: Temple University Press.

Adorno, T.W., Frenkel-Brunswik, E., Levinson, D.J., \& Sanford, R.N. (1950). The authoritarian personality. New York: Harper \& Row.

Alcoff, L., \& Potter, E. (Eds.). (1993). Feminist epistemologies. New York: Routledge.

Bacon, F. (1965). Francis Bacon: A selection of his works (S. Warhaft, Ed.). Toronto: Macmillan.

Barkan, E. (1992). The retreat of scientific racism: Changing concepts of race in Britain and the United States between the world wars. Cambridge: Cambridge University Press.

Bhatia, S., \& Ram, A. (2001). Rethinking 'acculturation' in relation to diasporic cultures and postcolonial identities. Human Development, 44(1), 1-18.

Broca, P. (1864). On the phenomena of hybridity in the genus homo. London: Longman, Green, Longman, \& Roberts, Paternoster Row.

Cavalli-Sforza, L.L., \& Cavalli-Sforza, F. (1995). The great human diasporas: The history of diversity and evolution. Reading, MA: Addison-Wesley.

Choi, I., Nisbett, R.E., \& Norenzayan, A. (1999). Causal attribution across cultures: Variation and universality. Psychological Bulletin, 125(1), 47-63.

Collins, P.H. (1991). Black feminist thought: Knowledge, consciousness, and the politics of empowerment. New York: Routledge.

Corcos, A. (1997). The myth of human races. East Lansing: Michigan State University Press.

Crawford, M., \& Unger, R. (2000). Women and gender: A feminist psychology. New York: McGraw-Hill.

Danziger, K. (1997). Naming the mind: How psychology found its language. London: Sage.

Davenport, C.B., \& Steggerda, M. (1929). Race crossing in Jamaica. Washington, DC: Carnegie Institute of Washington.

Dilthey, W. (1959). Einleitung in die Geisteswissenschaften (Gesammelte Schriften I. Band) [Introduction to the human sciences (Collected Writings, Vol. 1)]. Stuttgart: Teubner (Original work published 1883.)

Dovidio, J.F., \& Gaertner, S.L. (Eds.). (1986). Prejudice, discrimination, and racism. Orlando, FL: Academic Press.

Dussel, E. (1995). The invention of the Americas: Eclipse of 'the other' and the myth of modernity (M.D. Barber, Trans.). New York: Continuum. (Original work published 1992.)

Ernst, W., \& Harris, B. (Eds.). (1999). Race, science and medicine, 1700-1960. London: Routledge.

Essed, P. (1991). Understanding everyday racism: An interdisciplinary theory. Newbury Park, CA: Sage.

Fancher, R.E. (2001). Eugenics and other Victorian 'secular religions'. In C.D. Green, M. Shore, \& T. Teo (Eds.), The transformation of psychology: Influences 
of 19th-century philosophy, technology, and natural science (pp. 3-20). Washington, DC: American Psychological Association.

Febbraro, A.R. (1997). Gender, mentoring, and research practices: Social psychologists trained at the University of Michigan, 1949-1974. Unpublished doctoral dissertation, University of Guelph, Ontario.

Foucault, M. (1970). The order of things: An archaeology of the human sciences (A. Sheridan-Smith, Trans.). London: Tavistock. (Original work published 1966.)

Gaertner, S.L., \& Dovidio, J.F. (1986). The aversive form of racism. In J.F. Dovidio \& S.L. Gaertner (Eds.), Prejudice, discrimination, and racism (pp. 61-86). Orlando, FL: Academic Press.

Gergen, K.J., \& Gergen, M.M. (1984). Ethnocentrism. In R.J. Corsini (Ed.), Encyclopedia of psychology (Vol. 1, pp. 455-456). New York: Wiley.

Gilligan, C. (1982). In a different voice. Cambridge, MA: Harvard University Press.

Gould, S.J. (1996). The mismeasure of man (revised and expanded). New York: Norton.

Guthrie, R.V. (1998). Even the rat was white: A historical view of psychology (2nd ed.). Boston, MA: Allyn \& Bacon.

Hannaford, I. (1996). Race: The history of an idea in the West. Baltimore, MD: Johns Hopkins University Press.

Harding, S.G. (1986). The science question in feminism. Ithaca, NY: Cornell University Press.

Harding, S.G. (1991). Whose science? Whose knowledge? Thinking from women's lives. Ithaca. NY: Cornell University Press.

Harding, S.G. (1998). Is science multicultural? Postcolonialisms, feminisms, and epistemologies. Bloomington: Indiana University Press.

Harré, R. (2000). One thousand years of philosophy: From Ramanuja to Wittgenstein. Oxford: Blackwell.

Hegel, G.W.F. (1986). Phänomenologie des Geistes [Phenomenology of the mind]. Frankfurt am Main: Suhrkamp. (Original work published 1807.).

Helmholtz, H. (1903). Ueber das Sehen des Menschen [On human vision]. In Vorträge und Reden: Erster Band (5. Auflage) [Lectures and papers: Vol. 1 (5th ed.) ] (pp. 87-117). Brunswick: Vieweg.

Holzkamp, K. (1973). Sinnliche Erkenntnis: Historischer Ursprung und gesellschaftliche Funktion der Wahrnehmung [Sensory knowledge: Historical origin and societal function of perception]. Frankfurt am Main: Athenäum.

Holzkamp, K. (1983). Grundlegung der Psychologie [Foundation of psychology]. Frankfurt am Main: Campus.

Howitt, D., \& Owusu-Bempah, J. (1994). The racism of psychology: Time for change. New York: Harvester Wheatsheaf.

Jones, J.M. (1997). Prejudice and racism (2nd ed.). New York: McGraw-Hill.

Kant, I. (1968). Kritik der reinen Vernunft [Critique of pure reason] (2 vols.) (W. Weischedel, Ed.). Frankfurt am Main: Suhrkamp. (Original work published 1781.)

Keller, E.F. (1985). Reflections on gender and science. New Haven, CT: Yale University Press.

Kohlberg, L. (1981). Essays on moral development, Vol. I: The philosophy of moral development. San Francisco, CA: Harper \& Row. 
Kohlberg, L. (1984). Essays on moral development, Vol. II: The psychology of moral development. San Francisco, CA: Harper \& Row.

Kuhn, T.S. (1962). The structure of scientific revolutions. Chicago, IL: University of Chicago Press.

Lange, F.A. (1950). The history of materialism and criticism of its present importance (E.C. Thomas, Trans.). New York: The Humanities Press. (Original work published 1866.)

Levin, M. (1997). Population differentiation and racial classification. In R. Dulbecco (Ed.), Encyclopedia of human biology (Vol. 7 [Po-Se], 2nd ed., pp. 33-39). San Diego, CA: Academic Press.

Malik, K. (1996). The meaning of race: Race, history and culture in Western society. New York: New York University Press.

Marx, K., \& Engels, F. (1958). Die deutsche Ideologie [The German ideology]. In K. Marx \& F. Engels, Werke Band 3 [Works: Vol. 3] (pp. 9-530). Berlin: Dietz. (Original work 1845-6, published 1932.)

Mecheril, P., \& Teo, T. (Eds.). (1997). Psychologie und Rassismus [Psychology and racism]. Reinbek: Rowohlt.

Memmi, A. (2000). Racism. Minneapolis: University of Minnesota Press. (Original work published 1982.)

Miles, R. (1989). Racism. London: Routledge.

Montagu, A. (1974). Man's most dangerous myth: The fallacy of race (5th ed., revised and enlarged). New York: Oxford University Press.

Müller-Freienfels, R. (1936). Psychologie der Wissenschaft [Psychology of science]. Leipzig: Barth.

Paranjpe, A.C. (1998). Self and identity in modern psychology and Indian thought. New York: Plenum.

Penelope, J. (1990). Speaking freely: Unlearning the lies of the fathers' tongues. New York: Pergamon.

Prakash, G. (1999). Another reason: Science and the imagination of modern India. Princeton, NJ: Princeton University Press.

Reichenbach, H. (1938). Experience and prediction: An analysis of the foundations and the structure of knowledge. Chicago, IL: University of Chicago Press.

Richards, G. (1997). 'Race', racism and psychology: Towards a reflexive history. London: Routledge.

Rushton, J.P. (1999). Race, evolution, and behavior (special abridged ed.). Somerset, NJ: Transaction.

Said, E.W. (1979). Orientalism. New York: Random House.

Said, E.W. (1993). Culture and imperialism. New York: Knopf.

Samelson, F. (1978). From 'race psychology' to 'studies in prejudice': Some observations on the thematic reversal in social psychology. Journal of the History of the Behavioral Sciences, 14(3), 265-278.

Shelton, J.N. (2000). A reconceptualization of how we study issues of racial prejudice. Personality and Social Psychology Review, 4(4), 374-390.

Spencer, H. (1972). On social evolution: Selected writings (J.D.Y. Peel, Ed.). Chicago, IL: University of Chicago Press.

Spivak, G.C. (1999). A critique of postcolonial reason: Toward a history of the vanishing present. Cambridge, MA: Harvard University Press. 
Stegmüller, W. (1979). Hauptströmungen der Gegenwartsphilosophie [Main currents of contemporary philosophy). Stuttgart: Kröner.

Stepan, N. (1982). The idea of race in science: Great Britain 1800-1960. London: Macmillan.

Stoltenberg, J. (1989). Refusing to be a man: Essays on sex and justice. Portland, OR: Breitenbush Books.

Tate, C., \& Audette, D. (2001). Theory and research on 'race' as a natural kind variable in psychology. Theory \& Psychology, 11(4), 495-520.

Tavris, C. (1992). The mismeasure of woman. New York: Simon \& Schuster.

Teo, T. (1998). Klaus Holzkamp and the rise and decline of German critical psychology. History of Psychology, 1(3), 235-253.

Teo, T. (1999a). Methodologies of critical psychology: Illustrations from the field of racism. Annual Review of Critical Psychology, 1, 119-134.

Teo, T. (1999b). Functions of knowledge in psychology. New Ideas in Psychology, $17(1), 1-15$.

Teo, T. (2001). Karl Marx and Wilhelm Dilthey on the socio-historical conceptualization of the mind. In C. Green, M. Shore, \& T. Teo (Eds.), The transformation of psychology: Influences of 19th-century philosophy, technology and natural science (pp. 195-218). Washington, DC: American Psychological Association.

Teo, T. (2002). Friedrich Albert Lange on neo-Kantianism, socialist Darwinism, and a psychology without a soul. Journal of the History of the Behavioral Sciences, $38,285-301$.

Teo, T., Becker, G., \& Edelstein, W. (1995). Variability in structured wholeness: Context factors in L. Kohlberg's data on the development of moral judgment. Merrill-Palmer Quarterly, 41(3), 381-393.

Tolman, C.W. (1994). Psychology, society, and subjectivity: An introduction to German critical psychology. London: Routledge.

Tucker, W.H. (1994). The science and politics of racial research. Urbana, IL: University of Illinois Press.

Weidman, N. (1999). Constructing scientific psychology: Karl Lashley's mind-brain debates. Cambridge: Cambridge University Press.

Weingart, P., Kroll, J., \& Bayertz, K. (1988). Rasse, Blut und Gene: Geschichte der Eugenik und Rassenhygiene in Deutschland [Race, blood, and genes: History of eugenics and racial hygiene in Germany]. Frankfurt am Main: Suhrkamp.

Winston, A.S. (1996). The context of correctness: A comment on Rushton. Journal of Social Distress and the Homeless, 5(2), 231-250.

ACKNOWLEDGEMENTS. This article is part of a Social Sciences and Humanities Research Council of Canada-funded research program on the 'History and Theory of the Concept of Race and Racism in Psychology'. We would also like to thank Christopher Green for his helpful comments on the manuscript.

Thomas Teo is Associate Professor of Psychology in the History and Theory of Psychology Program at York University, Toronto, Canada. His research focuses on psychology as a critical human science, and includes 
historical, methodological and epistemological studies. He has published on race and racism in psychology, theoretical problems of developmental, critical and liberation psychology, and the history of 19th-century German psychology. ADDREss: Department of Psychology, York University, 4700 Keele Street, Toronto, Ontario, M3J 1P3, Canada. [email: tteo@yorku.ca]

Angela R. Febbraro is a defence scientist at Defence Research \& Development Canada-Toronto (Command Effectiveness \& Behaviour Section, Leadership \& Trust Group). She received her Ph.D. at the University of Guelph in Applied Social/Developmental Psychology. Her current research and writing interests are in the areas of gender, ethnicity, leadership and organizations, with an emphasis on women's roles in military, scientific and other non-traditional workplaces. ADDREss: Defence Research \& Development Canada-Toronto, 1133 Sheppard Ave. West, PO Box 2000, Toronto, Ontario, Canada, M3M 3B9.

[email: Angela.Febbraro@drdc-rddc.gc.ca] 